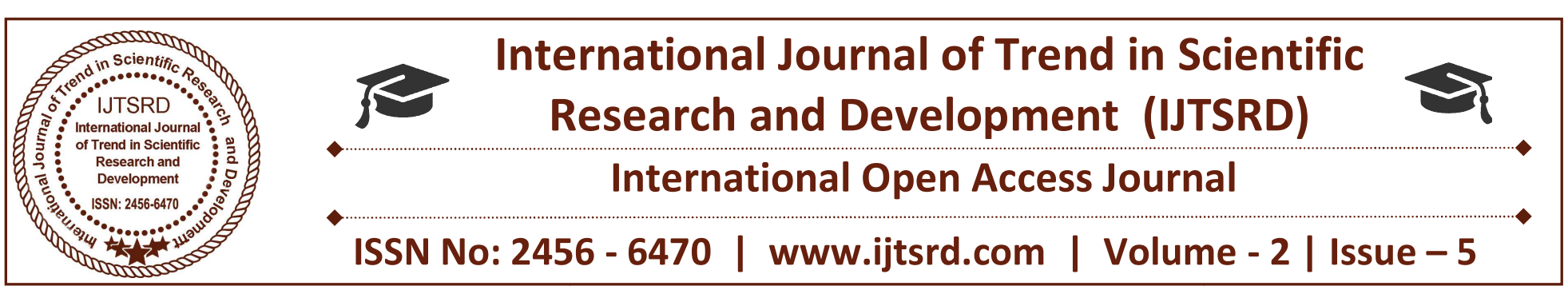

\title{
The Legal Viability of "Non Pregnancy Clauses" in Film Contract - Legal Analysis
}

\author{
Ayush Kumar Verma \\ B.A., L.L.B. (Hons), Indore Institute of Law, \\ Indore, Madhya Pradesh, India
}

\section{INTRODUCTION}

An NPC in film contracts prohibits an actress from getting pregnant until completion of principal photography for the film, a breach of which leads to the dismissal of the actress and/or a claim for damages1. The consideration of such a provision is attributed to the trouble related with shooting complicated scenes with the pregnant actress because of health concerns, the development of mid-riff of an actress upon pregnancy, which is in accordance with the script, and the disturbance in the shooting plan in light of inaccessibility of the performer on the agreed dates, prompting budgetary loss for the producer.

These provisions have been utilized for some time in numerous different countries and have currently crept in the Indian film industry too, with increased number of foreign studios making films here. Until now, a NPC has reportedly been used only once in the Indian film industry, when producer Subhash Ghai contracted with actress Madhuri Dixit, for the film 'Khalnayak', during the time she was in a serious relationship with actor Sanjay Dutt2. Short while ago, actress Aishwaraya Rai Bachchan did not appear for the film 'faishon' which was eventually marked by Priyanka Chopra.

In this background, it is hypothesized that the producers are anxious to fence themselves against

\footnotetext{
${ }^{1}$ Available at https://www.villagevoice.com/2011/08/01/wehave-obtained-a-copy-of-mtvs-standard-real-world-castmember-contract /

2 Independent Evaluation Of The ILO's Strategies On Fundamental Principles And Rights At Work, International Labour Organisation 73 (Vol.2, 2015), available at, http://www.ilo.org/wcmsp5/groups/public/---ed_mas/--eval/documents/publication/wcms_374259.pdf
}

risks emerging out of an actress' pregnancy, soon such conditions will turn into the standard in Indian film industry also, to the degree of existing contracts being improved. Many of the stakeholders believes that the connection amongst an actress and producers in the industry in India is based on trust. Henceforth, it is likely that arrangements and mutual understanding won't be supplanted by such contracts.

Anyway it should be recalled that compromises by method for transactions can't occur when the parties have unequal dealing powers. For example, on account of backstage craftsmen opposite the producer, and so forth. This underlines the significance of averting dependence on contract law in such manner.

It is important to note that regardless of whether a NPC is proclaimed invalid so far as movies are concerned, the worries of an actress won't get tended to. This is on the grounds that there is no relating obligation on the maker to end the film/serial when an actress is fit to shoot once again. Therefore, when the shooting for the movie hasn't yet begun, or when it is conceivable to recast the specific part in spite of the shooting of the movie have begun, while the onscreen character can't be rejected, the directors can recast her part. Essentially, when there is a settled term contract, there is a possibility that the term of the agreement will lapse when an actress has returned to work.

\section{Non Pregnancy Clause Verses Labour law}

The major labour legislation governing maternity benefits in India is the Maternity Benefits Act, 
1961.3 It applies "to every establishment being a factory, mine or plantation including any such establishment belonging to Government and to every establishment wherein persons are employed for the exhibition of equestrian, acrobatic and other performances" and to "every shop or establishment" 4 as per state laws, in which 10 or more persons are employed on any day of the preceding twelve months (section2 (1)).

An argument can be made that actresses are "employed for the presentation of different performance", where 'for' is to be read to mean having a nexus with the show, and not in particular for the display of exhibitions. This is without a doubt an exceptionally far reaching perusing, and there is no legal direction on whether this course will be taken by the courts.

Therefore, while there is no guidance available from judicial precedents, there is a probability that the production houses will fall inside the sphere of organizations secured by the 1961 Act, particularly when states accept the Model Shops and Establishments (Regulation of Employment and Conditions of Service) Bill, 2016.

\section{Non Pregnancy Clause Verses Law of Contract, 1872}

Section 23 of the Indian Contract Act, 1872 stipulates that 'an agreement of which the object or consideration is unlawful is void'. The object or consideration is unlawful as per the Section inter alia if it is 'forbidden by law', or the Court regards it as 'opposed to public policy' 5.

On the other hand, it can be argued that actress makes a portrayal of being accessible for the film all through the term of the agreement and expecting that much of the time, pregnancy is an arranged activity, her arranging pregnancy amid this period is a deception and a break of trust. The teaching of generous nonexecution, which takes into account bosses to fire the worker without notice can likewise be utilized, in situations where the pregnancy prompts her

\footnotetext{
3 The Maternity Benefit (Amendment) Bill, 2016, available at http://www.prsindia.org/billtrack/the-maternity-benefitamendment-bill-2016-4370/

4 Ibid 3

${ }^{5}$ Daryao v State of Uttar Pradesh, AIR 1961 SC 1457;

Olga Tellis v. Bombay Municipal Corporation, [1985] 2

Supp SCR 51
}

powerlessness to play out a considerable part of the agreement.

\section{Non Pregnancy Clauses Verses Fundamental Rights}

The privilege to correspondence square (Articles 14 and 15) and the privilege to life (Article 21) become an integral factor while distinguishing the defend ability of NPCs. Before we start the investigation, it should be reminded that while Articles 14 and 15 are accessible just against the state as characterized under Article 12 of the Constitution, Article 21 is likewise accessible against private people. Indeed, even so far as the uniformity square is concerned the guideline of roundabout horizontality can be utilized to uphold the key ideal to equity against private people.

The legitimacy of a NPC opposite Article 14 can be tried at two levels. At the primary level of nondiscrimination, (requiring the fulfillment of trial of sensible nexus of the characterization with the question and comprehensible differentia) Supreme Court's case in Air India v. Nergesh Meerza6 is as yet the substantial law. The court there, without talking about whether the idea of the work being really performed by the two posts in the said case was extraordinary, held that as long as the separation is done between two separate posts, it won't add up to segregation since the two posts are not equivalent at the primary spot.

Anyway ensuing cases have gained ground in such manner, both on the front of ideal to correspondence and in conceiving the privilege to parenthood inside the ambit of Article 21. In Inspector (Mahila) Ravina v. Association of India, CRPF denied advancement to a female controller since she was not able go to a prelimited time course as a result of her pregnancy. The Delhi High Court held that punishing a lady for her pregnancy was infringing upon Article 21, as deciphered in light of Articles 4232 and 45.33 As the case concerned open work, it was likewise held to be unfair according to Article 16 of the Constitution (this thinking additionally winds up appropriate to Article 14 and 15).

In this backgroung, it can be contended that a NPC provision will be violative of Articles 14, 15 and 21. Anyway not presently, the film business has certain curious highlights demonstrated in the start of this

\footnotetext{
${ }^{6}(1981) 4$ SCC 335
} 
paper and as itemized underneath, which may help the courts in characterizing a NPC as a simple grouping and not separation.

\section{Conclusion}

A NPC prohibits an actress from getting pregnant until finish of primary photography for the film. A rupture of this provision brings about rejection of the performer. So far as Labor Law is concerned, it is likely that a NPC will be negated by the nonderogatory arrangements of the Maternity Benefits Act, 1961. Under the Indian Contract Act, 1872, read in the light of the statute on fundamental rights and the Maternity Benefits Act, 1961, these provisions can likewise be said to be against the general population arrangement of India, and thus invalid according to section 23 of the Act.

Anyway it can be contended that pregnancy would bring about considerable non execution of the settled term film contract, in this way taking into account disavowal of the agreement by the counter party, the maker, as a result prompting end of the performing artist's work. The condition is seemingly infringing upon Article 14, 15,16and 21of the Indian Constitution, unless the impossible to miss highlights of the film business, where the matter of the creation house is reliant on the continuation of the work of the performing actress, may influence the Indian courts in holding a NPC as a substantial characterization rather than a separation just based on sex. ILO's Discrimination (Employment and Occupation) Convention ,1958 which India endorsed in June 1960 would make India at risk for non acquaintance of laws with deference with non separation based on sex in all types of work at the global level. Anyway India hasn't yet presented a law executing this Convention at the nation level. It will likewise be use full if the Film Guild Association takes lead in definition of rules in this regard. As per the situation in such manner somewhere else on the planet, while the statute in the United States shows that a NPC would fall inside the BFOQ exemption under the Title VII of the Civil Rights Act of 1964, the European Court of Justice is probably going to translate this condition as that advancing segregation based sex. All in all, there is no definitive response to the lawful legitimacy of the statements. 